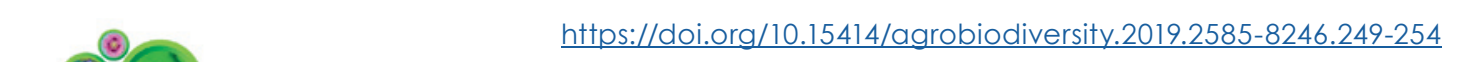

AGROBIODIVERSITY

FOR IMPROVING NUTRITION, HEALTH AND LIFE QUALITY 2019

$\Theta$

\title{
IDENTIFICATION OF TUNISIAN CASTOR GENOTYPES (RICINUS COMMUNIS L.) USING SCOT MARKERS
}

\section{Vivodík Martin $^{1}{ }^{*}$, Ezzeddine Saadaoui $^{2}$, Petrovičová Lenka ${ }^{1}$, Balážová Želmíra ${ }^{1}$, Gálová Zdenka ${ }^{1}$}

${ }^{1}$ Slovak University of Agriculture in Nitra, Faculty of Biotechnology and Food Sciences, Department of
Biochemistry and Biotechnology, Nitra, Slovak Republic
${ }^{2}$ University of Carthage, National Institute of Research in Rural Engineering, Waters and Forests
(INRGREF), Regional Station of Gabès, BP 67, Gabès Manara, 6011, Tunisia

Received: 18. 6. 2019 Revised: 28. 10. $2019 \quad$ Published: 30. 11. 2019

In the present investigation, 20 genotypes of Tunisian castor were analyzed using 5 start codon targeted (SCoT) markers. These primers produced total 33 fragments across 20 Tunisian castor genotypes, of which $26(78.70 \%)$ were polymorphic with an average of 5.20 polymorphic fragments per primer and number of amplified fragments ranged from 4 (SCoT 66) to 9 (SCoT 65). The polymorphic information content (PIC) value ranged from 0.652 (ScoT 65) to 0.816 (SCoT 61) with an average of 0.738. The dendrogram based on hierarchical cluster analysis using UPGMA algorithm was prepared. The hierarchical cluster analysis showed that the Tunisian castor genotypes were divided into 3 main clusters. Cluster 1 contained 4 castor genotypes from region Gabes (G-1, G-2, G-4 and G-5). Cluster 2 contained 4 castor genotypes from region Mornag (M-1, M-2, M-4, M-5). Cluster 3 contained 12 Tunisian castor genotypes and was divided into subcluster $3 \mathrm{a}, 3 \mathrm{~b}$, and 3c. Subcluster 3a contained one genotype from region Mornag (M-3), one genotype from region Mednine (MD-5) and 2 genotypes from the region Kebili (K-2 and K-3). Subcluster 3b contained 2 castor genotypes from region Kebili (K-1 and K-5). Subclaster 3c contained five genotypes from region Ksar jedid (KJ-1, KJ-2, KJ-3, KJ-4, KJ-5) and one genotype from region Kebili (K-4). Two Tunisian castor genotypes of 3c subcluster (K-1 nad K-4) were genetically the closest. We can assume that they have a close genetic background. The present study shows the effectiveness of employing SCoT markers in analysis of castor and would be useful for further studies in population genetics, conservation genetics, and genotypes improvement.

Keywords: Tunisian Ricin, molecular markers, SCoT analysis, polymorphism, dendrogram, PIC

\section{Introduction}

Castor bean (Ricinus communis L.) has recently been highly rated as a source of raw material (oil) for biodiesel production, because beyond its high oil content (25-55\%), it is a culture of great social appeal in Brazil by intensive use of workmanship in the field and allows

\footnotetext{
*Corresponding author: Martin Vivodik, Slovak University of Agriculture in Nitra, Faculty of Biotechnology and Food Sciences, Department of Biochemistry and Biotechnology, Tr. Andreja Hlinku 2, 949 76, Nitra, Slovak Republic $\triangle$ vivodikmartin@gmail.com
} 
for intercropping with other crops like beans, groundnuts or maize (Madail et al., 2007). In addition, castor bean cultivation is encouraged in areas of low water availability and is genetically improved to produce biofuel (Evangelista et al., 2004).

These types of molecular techniques included random amplified polymorphic DNA (RAPD) (Štefúnová et al., 2015), amplified fragment length polymorphism (AFLP) (Molin et al., 2013), inter-simple sequence repeat (ISSR) (Žiarovská et al., 2013) and simple sequence repeats (SSRs) (Shehata et al., 2009). These marker systems are useful for biodiversity analyses, phylogenetic studies, germplasm management, cultivar identification, and other applications (Luo et al., 2010). Recently, a simple novel DNA marker technique namely start codon targeted (SCoT) polymorphism, was developed by Collard and Mackill (2009). Primers for SCoT marker analysis were designed from the conserved region surrounding the translation initiation codon, ATG (Sawant et al., 1999). Suitability of SCoT markers for the construction of genetic maps, fingerprinting and phylogenetic studies has been proved by many authors. In many crops, such as citrus (Mahjbi et al., 2015) and castor (Kallamadi et al., 2015).

The goals of this study were to examine the effectiveness of SCoT markers (SCoT 66, SCoT 65, SCoT 63, SCoT 62, SCoT 61) for analysis of genetic diversity of Tunisian castor and to study genetic relationships among 20 Tunisian castor accessions.

\section{Material and methods}

\section{Plant material and DNA extraction}

Ricin lines (20) were obtained from the University of Carthage, National Institute of Research in Rural Engineering, Waters and Forests (INRGREF), Regional Station of Gabès, Tunisia. Regions of origin of analyzed genotypes of Tunisian ricin: KJ - Ksar jedid, K - Kebili, G - Gabes, M - Mornag, MD - Mednine. Genomic DNA was isolated from the 14 days leaves with GeneJET Plant Genomic DNA Purification Mini Kit according to the manufacturer's instructions. Castor genotypes were grown in a growth chamber on humus soil.

\section{SCoT amplification and statistical analysis}

A total of 5 SCoT primers (SCoT 66, SCoT 65, SCoT 63, SCoT 62, SCoT 61) developed by Collard and Mackill (2009) were selected for the present study (Table 1). Each $15 \mu \mathrm{L}$ amplification reaction consisted of $1.5 \mu \mathrm{L}(100 \mathrm{ng}$ ) template DNA, 7.5 $\mu \mathrm{L}$ Master Mix (Genei, Bangalore, India), $1.5 \mu \mathrm{L} 10 \mathrm{pmol}$ primers, and $4.5 \mu \mathrm{L}$ distilled water. Amplification was performed in a programmed thermocycler (Biometra, Germany) using the following program: $94{ }^{\circ} \mathrm{C}$ for $3 \mathrm{~min}$; 35 cycles of $94^{\circ} \mathrm{C}$ for $1 \mathrm{~min}, 50^{\circ} \mathrm{C}$ for $1 \mathrm{~min}$, and $72^{\circ} \mathrm{C}$ for $2 \mathrm{~min}$; a final extension at $72{ }^{\circ} \mathrm{C}$ for $5 \mathrm{~min}$. Amplified products were separated on 1.5\% agarose in $1 \times$ TBE buffer. The gels were stained with ethidium bromide and documented using gel documentation system Grab-It 1D pre-Windows.

The SCoT bands were scored as present (1) or absent (0), each of which was treated as an independent character regardless of its intensity. The binary data generated were used to estimate the level of polymorphism by dividing the polymorphic bands by the total number of scored bands and to prepare a dendrogram. A dendrogram was constructed based on 
hierarchical cluster analysis using the unweighted pair group method with arithmetic average (UPGMA) with the help of SPSS professional statistics version 17 software package. For the assessment of the polymorphism between genotypes maize and usability SCoT markers in their differentiation, we used polymorphic information content (PIC) (Weber, 1990).

Table 1 List of used SCoT primers (Collard and Mackill, 2009)

\begin{tabular}{ll}
\hline SCoT Primers & Primer sequence $\left(\mathbf{5}^{\prime}-\mathbf{3}^{\prime}\right)$ \\
\hline SCoT 66 & ACCATGGCTACCAGCGAG \\
SCoT 65 & ACCATGGCTACCACGGCA \\
SCoT 63 & ACCATGGCTACCACGGGC \\
SCoT 62 & ACCATGGCTACCACGGAG \\
SCoT 61 & CAACAATGGCTACCACCG \\
\hline
\end{tabular}

\section{Results and discussion}

In this work, 5 primers were screened for PCR amplification of DNA and SCoT analysis in 20 Tunisian castor genotypes. Table 1 and Table 2 shows sequences of these primers, the total number of amplified fragments from 20 Tunisian castor genotypes, the number of polymorphic bands and the polymorphic information content for each primer. Five primers produced 33 DNA fragments (Table 2) with an average of 6.60 bands per primer. From these five primers, primers SCoT 65 was the most polymorphic, where 9 polymorphic amplification products were detected. The lowest number of amplified polymorphic fragments (4) was detected by primer SCoT 66. Of the 33 amplified bands, 26 (78.70\%) were polymorphic, with an average of 5.20 polymorphic bands per primer. To determine the level of polymorphism in the analyzed group of castor genotypes, polymorphic information content (PIC) was calculated (Table 2).

Table 2 The statistical characteristics of the SCoT markers used in castor

\begin{tabular}{lcccc}
\hline $\begin{array}{l}\text { SCoT } \\
\text { Primers }\end{array}$ & $\begin{array}{c}\text { Total number } \\
\text { of bands }\end{array}$ & $\begin{array}{c}\text { Number of } \\
\text { polymorphic bands }\end{array}$ & $\begin{array}{c}\text { Percentage of } \\
\text { polymorphic bands (\%) }\end{array}$ & PIC \\
\hline SCoT 66 & 4 & 3 & 75.00 & 0.729 \\
SCoT 65 & 9 & 7 & 77.78 & 0.652 \\
SCoT 63 & 8 & 6 & 75.00 & 0.780 \\
SCoT 62 & 5 & 4 & 80.00 & 0.715 \\
SCoT 61 & 7 & 6 & 85.71 & 0.816 \\
Average & 6.60 & 5.20 & 78.70 & 0.738 \\
Total & 33 & 26 & - & - \\
\hline
\end{tabular}

The polymorphic information content (PIC) value ranged from 0.652 (ScoT 65) to 0.816 (SCoT 61) with an average of 0.738 . The dendrogram of genetic relationships among 20 Tunisian castor genotypes based on 5 SCoT markers was constructed (Figure 1). 


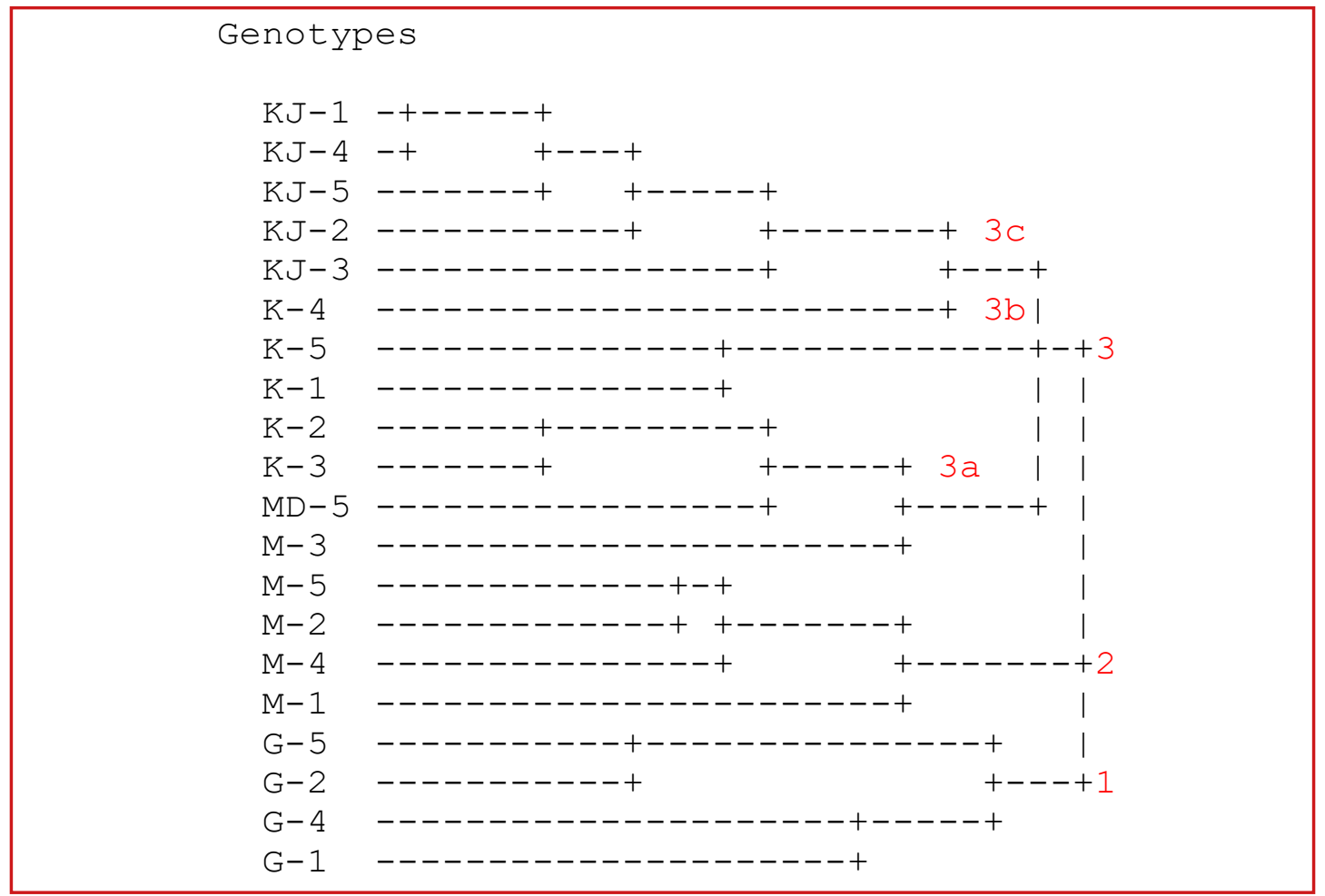

Figure 1 Dendrogram of 20 Tunisian castor genotypes prepared based on 5 SCoT markers. Regions of origin of analyzed genotypes of Tunisian ricin

KJ - Ksar jedid; K - Kebili; G - Gabes; M - Mornag; MD - Mednine

The hierarchical cluster analysis showed that the Tunisian castor genotypes were divided into 3 main clusters. Cluster 1 contained 4 castor genotypes from region Gabes (G-1, G-2, G-4, and G-5). Cluster 2 contained 4 castor genotypes from region Mornag (M-1, M-2, M-4, M-5). Cluster 3 contained 12 Tunisian castor genotypes and was divided into subcluster $3 \mathrm{a}, 3 \mathrm{~b}$, and 3c. Subcluster 3a contained one genotype from region Mornag (M-3), one genotype from region Mednine (MD-5) and 2 genotypes from the region Kebili (K-2 and K-3). Subcluster 3b contained 2 castor genotypes from region Kebili (K-1 and K-5). Subcluster 3c contained five genotypes from region Ksar jedid (KJ-1, KJ-2, KJ-3, KJ-4, KJ-5) and one genotype from region Kebili (K-4). Two Tunisian castor genotypes of 3c subcluster (K-1 nad K-4) were genetically the closest. We can assume that they have a close genetic background (Figure 1). Lower average polymorphism (21\%) obtained by SCoT technique was detected by Kallamadi et al. (2015) who analysed molecular diversity of castor (Ricinus communis L.). Out of a total of 108 bands, 23 (21\%) were polymorphic with an average of 2.1 polymorphic bands per primer. The total number of bands per primer varied from 5 and 20 in the molecular size range of 100-3,000 bp. The PIC varied from 0.06 for SCoT28 to 0.45 for SCoT12 with an average of 0.24. In the present study of Vivodík et al. (2018), the representatives of the genus castor collected from 12 different parts of Tunisia were differentiated by the DNA fingerprinting patterns 
using 37 SCoT primers. PCR amplification of DNA using 37 primers for SCoT analysis produced 268 DNA fragments that could be scored in all 56 genotypes of Tunisian castor. The number of amplified fragments varied from 4 (SCoT 45, SCoT 31 and ScoT 17) to 10 (SCoT 3, SCoT 11, SCoT 14, SCoT 18 and SCoT 12). Of the 268 amplified bands 230 were polymorphic, with an average of 6.22 polymorphic bands per primer. To determine the level of polymorphism in the analysed group of Tunisian castor genotypes polymorphic information content (PIC) was calculated. The lowest values of polymorphic information content were recorded for SCoT 17 (0.411) and the the highest PIC values were detected for SCoT 14 (0.868) with an average of 0.751. Petrovičová et al. (2017) study genetic variability among the set of 45 rye genotypes using 8 SCoT markers. Amplification of genomic DNA of 45 genotypes, using SCoT analysis, yielded 114 fragments, with an average of 14.25 polymorphic fragments per primer. The hierarchical cluster analysis showed that the rye genotypes were divided into 2 main clusters. Chai et al. (2017) investigate the optimal number of individuals that may represent the genetic diversity of a single population, using Start Codon Targeted (SCoT) markers. Two cultivated varieties and two wild accessions were evaluated using five SCoT primers, also testing different sampling sizes: 1, 2, 3, 5, 8, 10, 20, 30, 40, 50, and 60 individuals. Cluster analysis by Unweighted Pair Group Method with Arithmetic Mean (UPGMA) and structure placed the 240 individuals into four distinct clusters. Balážová et al. (2017) used eighteen primers to study polymorfism of 8 oat genotypes. Altogether 153 different fragments were amplified of which 67 were polymorphic with an average number of 3.72 polymorphic fragments per genotype. The number of polymorphic fragments ranged from one (SCoT9, SCoT62) to nine (SCoT40). The polymorphic information content ranged from 0 (SCoT9, SCoT62) to 0.876 (SCoT40) with an average of 0.524 .

\section{Conclusion}

In summary, SCoT marker analysis was successfully developed to evaluate the genetic relationships among the genus castor accessions originated from the various area. The hierarchical cluster analysis showed that the Tunisian castor genotypes were divided into 3 main clusters. Cluster 1 contained 4 castor genotypes from region Gabes (G-1, G-2, G-4, and G-5). Cluster 2 contained 4 castor genotypes from region Mornag (M-1, M-2, M-4, M-5). Cluster 3 contained 12 Tunisian castor genotypes and was divided into subcluster $3 a, 3 b$, and 3c. Subcluster 3a contained one genotype from region Mornag (M-3), one genotype from region Mednine (MD-5) and 2 genotypes from the region Kebili (K-2 and K-3). Subcluster 3b contained 2 castor genotypes from region Kebili (K-1 and K-5). Subcluster 3c contained five genotypes from region Ksar jedid (KJ-1, KJ-2, KJ-3, KJ-4, KJ-5) and one genotype from region Kebili (K-4). Two Tunisian castor genotypes of 3c subcluster (K-1 and K-4) were genetically the closest. We can assume that they have a close genetic background. Polymorphism revealed by SCoT technique was so abundant and could be used for molecular genetics study of the castor accessions, providing high-valued information for the management of germplasm, improvement of the current breeding strategies, and conservation of the genetic resources of castor species. 


\section{Acknowledgments}

This work was co-funded by VEGA project No. 1/0246/18 (50\%) and KEGA project No. 025SPU-4/2018 (50\%).

\section{References}

BALÁŽOVÁ, Ž., GÁLOVÁ, Z., VIVODÍK, M., PETROVIČOVÁ, L., HORNYÁK GREGÁŇOVÁ, R. 2017. Molecular variability of oat based on gene specific markers. In Potravinarstvo Slovak Journal of Food Sciences, vol. 11(1), p. 332-337. https://dx.doi.org/10.5219/774

COLLARD, B.C.Y., MACKILL, D.J. 2009. Start codon targeted (SCoT) polymorphism: a simple, novel DNA marker technique for generating gene-targeted markers in plants. In Plant Mol. Biol. Rep., vol. 27, p. 86-93.

EVANGELISTA A.R., ABREU J.G., PER A.J. 2004. Avaliação da composição química de tortas de mamona e amendoim obtidas por diferentes métodos de extração de óleo. In Congresso Brasileiro de Mamona, no. 1, p. 213-218.

CHAI, X., DONG, R., LIU, W., WANG, Y., LIU, Z. 2017. Optimizing sample size to assess the genetic diversity in common Vetch (Vicia sativa L.) populations using Start Codon Targeted (SCoT) markers. In Molecules, vol. 22, p. 567-577. https://doi.org/10.3390/molecules22040567

KALLAMADIA, P.R., GANGA RAO NADIGATLAB, V.P.R., MULPURIB, S. 2015. Molecular diversity in castor (Ricinus communis L.). In Industrial Crops and Products, vol. 66, p. 271-281. http://dx.doi. org/10.1016/j.indcrop.2014.12.061

LUO, C., HE, X.H., CHEN, H., OU, S.J. et al. 2010. Analysis of diversity and relationships among mango cultivars using start codon targeted (SCoT) markers. Biochem. In Syst. Ecol., vol. 38, p. 1176-1184.

MADAIL J.C.M., BELARMINO L.C., NEUTZLING D.M. 2007. Aspectos Econômicos da mamona. In Sistemas de Produção. Embrapa, 11. ISSN 1806-9207.

MAHJBI, A., BARAKET, G., OUESLATI, A., SALHI-HANNACHI, A. 2015. Start Codon Targeted (SCoT) markers provide new insights into the genetic diversity analysis and characterization of Tunisian Citrus species. In Biochemical Systematics and Ecology, vol. 61, p. 390-398. http://dx.doi.org/10.1016/j. bse.2015.07.017

MOLIN, D., COELHO, C.J., MÁXIMO, D.S., FERREIRA, F.S., GARDINGO, J.R., MATIELLO, R.R. 2013. Genetic diversity in the germplasm of tropical maize landraces determined using molecular markers. In Genet. Mol. Res., vol. 12(1), p. 99-114.

PETROVIČOVÁ, L., BALÁŽOVÁ, Ž., VIVODÍK, M., GÁLOVÁ, Z. 2017. Detection genetic variability of Secale cereale L. by SCoT markers. In Potravinarstvo Slovak Journal of Food Sciences, vol. 11(1), p. 197202. https://dx.doi.org/10.5219/726

SHEHATA, A.I., AL-GHETHAR, H.A., AL-HOMAIDAN, A.A. 2009. Application of simple sequence repeat (SSR) markers for molecular diversity and heterozygosity analysis in maize inbred lines. In Saudi Journal of Biological Sciences, vol. 16, p. 57-62.

ŠTEFÚNOVÁ, V., BEŽO, M., ŽIAROVSKÁ, J., RAŽNÁ, K. 2015. Detection of the genetic variability of Amaranthus by RAPD and ISSR markers. In Pak. J. Bot., vol. 47(4), p. 1293-1301.

VIVODÍK, M., SAADAOUI, E., BALÁŽOVÁ, Ž., GÁLOVÁ, Z., PETROVIČOVÁ, L. 2018. Genetic diversity and population structure in Tunisian castor genotypes (Ricinus communis L.) detected using SCOT markers. In Potravinarstvo Slovak Journal of Food Sciences, vol. 12(1), p. 143-149. https://doi. org/10.5219/873

WEBER, J. L. 1990. Informativeness of human (dC-dA)n x (dG-dT)n polymorphism. In Genomics, vol. 7, p. 524-530.

ŽIAROVSKÁ, J., RAŽNÁ, K., LABAJOVÁ, M. 2013. Using of inter microsatellite polymorphism to evaluate gamma-irradiated Amaranth mutants. In Emir. J. Food Agric., vol. 25(9), p. 673-681. 